IZA DP No. 5065

The Phantom of the Opera: Cultural Amenities, Human Capital, and Regional Economic Growth

Oliver Falck

Michael Fritsch

Stephan Heblich

July 2010 


\title{
The Phantom of the Opera: Cultural Amenities, Human Capital, and Regional Economic Growth
}

\author{
Oliver Falck \\ Ifo Institute and CESifo \\ Michael Fritsch \\ University of Jena, \\ Max Planck Institute of Economics and DIW \\ Stephan Heblich \\ Max Planck Institute of Economics and IZA
}

Discussion Paper No. 5065

July 2010

IZA

P.O. Box 7240

53072 Bonn

Germany

Phone: +49-228-3894-0

Fax: +49-228-3894-180

E-mail: iza@iza.org

\begin{abstract}
Any opinions expressed here are those of the author(s) and not those of IZA. Research published in this series may include views on policy, but the institute itself takes no institutional policy positions.

The Institute for the Study of Labor (IZA) in Bonn is a local and virtual international research center and a place of communication between science, politics and business. IZA is an independent nonprofit organization supported by Deutsche Post Foundation. The center is associated with the University of Bonn and offers a stimulating research environment through its international network, workshops and conferences, data service, project support, research visits and doctoral program. IZA engages in (i) original and internationally competitive research in all fields of labor economics, (ii) development of policy concepts, and (iii) dissemination of research results and concepts to the interested public.
\end{abstract}

IZA Discussion Papers often represent preliminary work and are circulated to encourage discussion. Citation of such a paper should account for its provisional character. A revised version may be available directly from the author. 
IZA Discussion Paper No. 5065

July 2010

\section{ABSTRACT \\ The Phantom of the Opera: Cultural Amenities, Human Capital, and Regional Economic Growth ${ }^{*}$}

We analyze the extent to which endogenous cultural amenities affect the spatial equilibrium share of high-human-capital employees. To overcome endogeneity, we draw on a quasinatural experiment in German history and exploit the exogenous spatial distribution of baroque opera houses built as a part of rulers' competition for prestigious cultural amenities. Robustness tests confirm our strategy and strengthen the finding that proximity to a baroque opera house significantly affects the spatial equilibrium share of high-human-capital employees. Then, a cross-region growth regression shows that these employees induce local knowledge spillovers and shift a location to a higher growth path.

JEL Classification: H41, R11, J24

Keywords: cultural amenities, regional economic growth, human capital, Bohemians

Corresponding author:

Stephan Heblich

Max Planck Institute of Economics

Entrepreneurship, Growth, and Public Policy Group

Kahlaischestr. 10

D-07745 Jena

Germany

E-mail: heblich@econ.mpg.de

\footnotetext{
"We are grateful to Sascha Becker, Marcus Berliant, Thiess Buettner, Gilles Duranton, William Kerr, Martin Kocher, Jordi Jofre Monseny, F. Mike Scherer, Guido Schwerdt, Hans-Werner Sinn, Albert Solé-Ollé, Olav Sorenson, William Strange, Jens Suedekum, Matthew Turner, Silke Uebelmesser, Elisabet Viladecans-Marsal, Stephan Weiler, Ludger Woessmann, and the seminar participants in Barcelona, Duisburg, Munich, and Utrecht, as well the participants of the 2009 Annual Meeting of the Urban Economics Association in San Francisco for helpful comments. Parts of this paper were written while Falck was visiting Harvard University and Heblich was visiting the University of Toronto. They acknowledge the hospitality of these institutions. Susann Giese and Alexander Paeschke provided capable research assistance.
} 
IZA Discussion Paper No. 5065

July 2010

\section{NON-TECHNICAL SUMMARY}

Baroque rulers' pomposity and quest for prestige accidentally affect economic growth today. The theory that you can only spend what you have was not a popular one among the absolutistic rulers of this era and it was not uncommon for rulers to incur huge debts and engage in deficit spending in their quest for grandeur. One remnant of this time is the baroque opera houses that are still found throughout Germany. The regional distribution of baroque opera houses today suggests that it is not primarily the regions' historic economic prosperity that explains their existence. Based on this observation, the paper addresses the chicken and egg problem of whether economic success leads to a rich cultural life or vice versa.

In light of studies that illustrate the concentration of both bohemians and human capital in prospering cities, one might assume that a concentration of cultural amenities attracts human capital. However, it could just as easily be the other way around, where a concentration of human capital in the form of highly skilled workers who have not only an appreciation for artistic output, but for the money to indulge in that taste, will attract bohemians. In our empirical analyses, we find that proximity to one of 29 baroque opera houses across Germany has a positive effect on the regional share of high-human-capital employees which then stimulates regional growth.

Our advice to local policymakers is to be aware of the value of cultural amenities when competing for high-human-capital individuals. However, local policymakers should also carefully consider the possibility of unwanted side effects from redistributing resources to cultural amenities at the expense of other public spending or increased taxes because such a policy could result in relocation decisions by firms or individuals that do not value cultural amenities. 


\section{Introduction}

The connection between the presence of exogenous local amenities, such as weather conditions, and spatial differences in wages and rents has long attracted a great deal of interest. ${ }^{1}$ In the framework of a spatial equilibrium model, Roback (1982) shows that exogenous local amenities that are valued by employees are capitalized into rents and wages. In an extension of this model, Moretti (2004) distinguishes low-human-capital employees from high-human-capital employees, finding that only the latter value the local amenity. This model suggests a spatial equilibrium, with a larger share of high-human-capital employees in the high amenity location. In this paper, we focus on consumptive amenities and argue that especially high-human-capital individuals cherish the availability of cultural amenities, a hypothesis that is supported by reality. For example, a large survey of about half a million individuals in Germany finds that the highly educated full-time employed respondents who moved in the last 10 years in fact rank "cultural offerings and an interesting cultural scene" among the top five reasons for their location choice. ${ }^{2}$

The challenge in analyzing the effect of local cultural amenities on high-human-capital employees is that cultural amenities—as compared to natural amenities like weather-are not exogenously determined. Initially, the endogeneity issue arises from local high-human-capital individuals’ ability and willingness to pay for cultural services (Glaeser 2005). Additionally, local governments might compete for creative individuals by subsidizing cultural services. For instance, German municipal governments subsidized "music and theatre" with more than 35 Euro per capita in 2006 (Destatis 2008). Given the local government's budget constraint, subsidies for cultural services, other local public spending, e.g., for education, and local taxes

\footnotetext{
${ }^{1}$ See, e.g., Rosen (1974; 1979), Roback (1982; 1988), Blomquist et al. (1988), Gabriel and Rosenthal (2004), Gyourko and Tracy (1991), and Rappaport (2007) for research in this area and Bartik and Smith (1987) for an overview.

2 The "Perspektive Deutschland” (Perspective Germany) Survey by the McKinsey consultancy. For more details, see Buettner and Janeba (2009).
} 
are simultaneously determined (Gyourko and Tracy 1991). This gives rise to a second endogeneity problem when analyzing the effect of local cultural amenities on high-humancapital employees. In both cases, it is not possible to refer an observed share of high-humancapital individuals in a region to the cause of cultural amenities and, consequently, it is not not guaranteed that expenditures for cultural amenities do indeed attract high-human-capital individuals.

To overcome these endogeneity problems and identify a causal relationship between cultural amenities and the spatial concentration of high-human-capital employees, we exploit a quasinatural experiment in German history. During the Baroque era, absolutistic courts and churches competed with each other for musical talent. ${ }^{3}$ This competition was especially fierce in what is now Germany, which at that time and up until industrialization was politically fragmented into several hundred princedoms. Vaubel (2005) illustrates this nicely when he mentions that Thuringia alone, where the composer J. S. Bach grew up, contained 22 separate courts. ${ }^{4}$ Music was so highly regarded that "every local court (Hof) worth its salt had its own orchestra or band (Kapelle or Harmonie), and the more affluent courts maintained opera houses” (Scherer 2001a: 719). These opera houses, many of which still exist, acted as tangible symbols of their builders' prestige. However, the presence of one of these opera houses does not necessarily mean that the surrounding region was wealthy and prosperous enough to afford it; very often the rulers incurred vast debt and engaged in deficit spending in their quest for grandeur, (cf. Duchhardt 1992; Vierhaus 1984). In other words, we argue that baroque opera houses do not indicate regional wealth or predict future prosperity. Accordingly, proximity to these opera houses, which were the result of a competition for prestige between kings, dukes, and princes, should be exogenous to the distribution of high-human-capital employees that originates from the period of and after the Industrial Revolution. 
We find that proximity to a baroque opera house is a strong predictor of a region's equilibrium share of high-human-capital employees. In several robustness tests, we discuss confounding factors that might be correlated with both proximity to a baroque opera house and the local share of high-human-capital individuals. Including control variables that are measured at the baroque opera house location and that are likely to capture productive spillovers from that location to the region being investigated does not change our result. To further validate our argument that proximity to a baroque opera house is a valid explanation for the effect of cultural amenities, we construct counterfactual opera house locations. Using propensity score matching, we pinpoint, from the pool of locations not having an opera house, those locations that are the "twins" of locations that do have an opera house and test the impact of proximity to these counterfactuals on a location's share of human capital employees. We find no significant effect in this specification. We further illustrate the relevance of our strategy by showing that places with a baroque opera house differ from the counterfactual locations without a baroque opera house in size of their cultural scene, which is measured by their contemporary share of bohemians. ${ }^{5}$

Local governments, however, are interested not only in whether local cultural amenities attract high-human-capital individuals but, also in whether these high-human-capital individuals generate some form of local knowledge spillover. In the absence of positive spillovers, it is difficult for a local government to justify its use of taxpayer money to subsidize cultural amenities. Thus, we exploit the exogenous variation in the local share of high-human-capital individuals stemming from proximity to a baroque opera house and analyze the effect of the local level of human capital on a location's growth path. Endogenous

\footnotetext{
3 The early Baroque era started around 1600 and the late Baroque era lasted until the late $17^{\text {th }}$ century. We concentrate on the period 1650-1800, which is broadly the time between the end of the Thirty Years' War and the beginning of the Industrial Revolution. In the following, we refer to this whole period as the Baroque era.

${ }^{4} \mathrm{~J}$. S. Bach was born in 1685 so he would have been in Thuringia between then and around 1700.

${ }^{5}$ Both Jacobs (1961) and Florida (2002) use the expression "bohemians” in the context of economic geography to describe a location's cultural scene as local amenities. However, the expression itself was popularized much
} 
growth theories suggest that in the presence of some form of local knowledge spillovers, the local level of human capital should have a positive effect on a location's growth path. Applying an instrumental variable approach, we find that it is the local level of high-humancapital employees who value their proximity to a baroque opera house that shifts a location to a higher growth path.

The remainder of the paper is organized as follows. In Section 2, we provide a detailed description of the quasi-natural experiment in German history that provides us with an exogenous spatial distribution of cultural amenities, i.e., baroque opera houses. In Section 3, we analyze the effect of proximity to a baroque opera house on the spatial equilibrium share of high-human-capital employees and discuss a variety of confounding factors that might bias our estimates. In Section 4, we exploit this exogenous variation in the local share of highhuman-capital individuals to test the impact of the local level of human capital on a location's growth. We conclude, in Section 5, by discussing some of the implications of our findings.

\section{Baroque Opera Houses in Germany as a Quasi-Natural Experiment}

In the centuries following Charlemagne, France, Spain, England, and Habsburg Austria developed into states where power was wielded by a centralized sovereign. In contrast, the Holy Roman Empire became increasingly fragmented because the emperor had to buy the loyalty of kings, princes, and dukes within the empire by granting territorial and governance concessions. When the Treaty of Westphalia finally ended the Thirty Years' War and, by association, the Holy Roman Empire, in 1648, what we know as Germany today was comprised of hundreds of sovereign kingdoms, principalities, and dukedoms. This environment of political fragmentation continued until the German Empire was established in the second half of the $19^{\text {th }}$ century. During this same period, European instrumental music

earlier by Henri Murger's (1845) story collection "Scenes de la Vie de Boheme” which became the basis of Puccini's opera "La Bohème.” 
experienced its apogee with the Baroque era, the most famous composers of which came from politically fragmented areas of Germany and Italy (Scherer 2001a; Vaubel 2005). ${ }^{6}$ Elias (1991: 26) explains this conjunction of circumstances as the result of competition for prestige among rulers of principalities: ${ }^{7}$

In France and England the decisive musical positions were concentrated in the capitals, Paris and London, as a result of state centralization. A high-ranking musician in these countries therefore had no chance of escape if he fell out with his princely employer. There were no competing courts that could rival the king's in power, wealth and prestige, and that could have given refuge to, for example, a French musician who had fallen from favor. But in Germany and Italy there were dozens of courts and cities competing for prestige, and thus for musicians. It is no exaggeration to trace the extraordinary productivity of court music in the territories of the former German empire among other things to this figuration - to the rivalry for prestige of the many courts and the correspondingly high number of musical posts.

Based on these initial ideas, Scherer (2001b) analyzes the biographies of 645 composers born between 1650 and 1849 and traces the evolution of freelance music composition over this period. His findings suggest that freelance composing increased in intensity across this entire period. However, a market for music beyond what churches and the nobility could sustain only emerged well after 1800 when an increasingly wealthy middle class began paying to attend concerts and demanding sheet music for home entertainment. In Scherer's data, this change in the music scene is reflected by a significant increase in freelance composing activity by composers born in the period 1800-1849.

\footnotetext{
${ }^{6}$ Among these composers were Bach, Handel, Telemann, Haydn, Gluck, Beethoven, Mozart, and Vivaldi.

${ }^{7}$ Scherer (2004) provides empirical evidence in support of this assumption.
} 
These findings suggest that those opera houses built before the Industrial Revolution began making inroads into continental Europe in the middle of the $19^{\text {th }}$ century were primarily built for reasons of prestige. They resulted from the cultural competition between kings, dukes, and princes in a time when strategic marriages and war alliances, instead of economic factors, determined regional prosperity. Of course, one could argue that the funds needed to build a prestigious opera house did not just magically appear but must have been, at least to some degree, based in the region's economic status. However, as discussed by Duchhardt (1992) and Vierhaus (1984), the theory that that you can only spend what you have was not a popular one among the absolutistic rulers of this era. Indeed, it was not uncommon for rulers to incur huge debts and engage in deficit spending in their quest for grandeur.

By contrast, opera houses built during and after the Industrial Revolution were most likely built to meet a growing private demand for music, a demand chiefly driven by economic development that brought increasing wealth to some regions and their emerging bourgeoisie. Given that German regions have been and are still shaped by industrialization patterns, only opera houses that were built before 1800 can be viewed as being exogenous to today's regional development.

\section{$<<$ Figure 1 here $>>$}

Figure 1 maps the locations of the 29 stand-alone opera houses built before 1800. The map clearly shows that the baroque opera houses were not located solely in today's big cities such as Berlin, Munich, and Hamburg but also in several currently smaller cities such as Bautzen, Neustrelitz, Passau, and Stralsund. Table A1 in the Appendix provides further information about the opera houses and makes it apparent that our cut-off year of 1800 is not adhered to strictly, i.e., we also include three opera houses that were built shortly after 1800. However, excluding these three opera houses does not qualitatively change our results. We concentrate on stand-alone opera houses because even though many manors and castles had halls where 
traveling orchestras and groups performed, these artists were only passing through. They were not part of everyday life and thus cannot be considered as early cultural concentrations that may predict today's concentrations. By contrast, constructing an opera house was a significant commitment to the musical arts, involving the permanent maintenance of an orchestra, stage designers, and so forth.

\section{The Contemporary Distribution of High-Human-Capital Employees and}

\section{Local Cultural Amenities}

In this section we provide evidence for the impact of proximity to a baroque opera house on the spatial equilibrium share of high-human-capital employees. As argued above, we consider the spatial distribution of baroque opera houses to be exogenous to contemporary regional development, which, in turn, is related to the distribution of high human capital. To demonstrate that there is a causal connection between consumptive cultural amenities and the local share of high-human-capital individuals, we need to confirm that proximity to baroque opera houses is not correlated with confounding factors associated with the local share of high-human-capital employees. Thus, we extensively discuss sources of productive spillovers from the opera house locations that might provide alternative explanations for the presence of high-human-capital individuals and that would thus bias our estimates.

Basic specification: The level of analysis is German districts, i.e., NUTS3 regions (Landkreise). German districts have a mean size of 812.67 square kilometers. For the sake of simplicity, imagine each district as a circle, the average diameter of which is 32.17 kilometers. For each district, we calculate the Eucledian distance in kilometers from the district's capital to the closest baroque opera house. When the district's central city contains a baroque opera house, we set this distance to zero. We started with all 439 districts, covering 324 territorial districts and 115 city districts (kreisfreie Stadt or Stadtkreis), but then merged 
36 city districts (kreisfreie Städte) with the surrounding territorial districts if the capital of the surrounding territorial district coincides with a city district. For instance, the capital of the territorial district of Munich in Bavaria is the city of Munich which is also a city district (kreisfreie Stadt). This procedure avoids double counts of the minimum distance to the city district and the surrounding territorial district. We end up with 403 districts with an average distance to the closest baroque opera house of 51 kilometers. The distribution of the distance to the closest baroque opera house is shown in Figure 2.

Data on regional human capital are derived from the German Social Insurance Statistics. The German Social Insurance Statistics requires every employer to report information about each employee subject to compulsory social insurance. Thus, employees are not categorized by place of residence but by workplace (establishment). Our human capital measure is simply the share of employees subject to social insurance with a tertiary (university) degree over all employees subject to social insurance in a district. A district's average annual share of employees with a tertiary degree over the five years from 1999 to 2004 is about 7.5 percent with a standard deviation of 4.2 percent.

In a cross-region regression, we regress a district $i$ 's $(i=1, \ldots, 403)$ average annual share of employees with a tertiary degree $\bar{h}_{i}$ on the distance $d_{i j}$ to the closest baroque opera house location $j(j=1, \ldots, 29)$ :

$$
\bar{h}_{i}=\alpha+\beta_{1} d_{i j}+\beta_{2} y_{i t=0}+D_{i} \beta_{3}+\varepsilon_{i} .
$$

As our model could be compromised if regional prosperity and urbanization have an impact on a district's share of high-human-capital employees, we additionally control for initial GDP per capita $\mathrm{y}_{\mathrm{it}=0}$ and a set of district-type dummies (matrix $D_{i}$ ). These dummies are based on a standard classification of German districts (siedlungsstrukturelle Kreistypen) according to their density and their spatial status (cf. Federal Office for Building and Regional Planning 
2003). Districts are classified according to their density of economic activity (core city, highly congested, moderately congested, and rural) as well as their location in large agglomerations, urbanized regions, and rural areas (see Table A2 for more details). $\varepsilon_{i}$ is a standard error term.

\section{$<<$ Table 1 here $>>$}

The result of the basic specification is reported in Column 1 of Table 1 . Proximity to a baroque opera house is a strong predictor of the district's share of employees with a tertiary degree. The result suggests that, all else equal, for every 10 kilometers nearer to an opera house, the district's equilibrium share of employees with a tertiary degree increases 0.3 percentage points (which is about 4 percent above the sample mean).

Contemporary economic conditions at the baroque opera house location: Of course, the coefficient of the distance $d_{i j}$ to the closest baroque opera house can be interpreted as a causal effect of proximity to a cultural amenity only if this proximity is not correlated with other factors having an impact on the local share of high-human-capital individuals. The most prominent pathways would seem to run through productive spillovers from the baroque opera location $j$ to location $i$. Spillovers from pecuniary agglomeration externalities are probably best captured by current GDP per capita and population density in the closest baroque opera house location. To account for this, we additionally control for initial GDP per capita and the district type (according to the BBR 2003) of the closest opera house location $j$. This procedure results in very little change in distance coefficient compared to the basic specification (cf. Column 2 of Table 1); the difference between the two coefficients is not statistically significant.

Baroque-era economic conditions at the historic opera house location: Above, we argue that in the Baroque era, the presence of an opera house did not necessarily indicate regional prosperity. However, if we are wrong about this, and opera houses were built only in 
prosperous regions, such past prosperity could very well be the foundation for current economic prosperity. For example, think of geographic features that are determinative of long-run economic prosperity, including a region's suitability for agriculture, forestry, trade, and mining, all of which were the major sources of wealth before the Industrial Revolution and might still influence regional wealth today.

As argued by Combes et al. (in press), the characteristics of a region's soil are crucial to that region's success in an agrarian society. Accordingly, geological indicators of the suitability of a region's soil for agriculture and forestry should provide a meaningful insight into the distribution of regional wealth prior to the heyday of industrialization. A region's soil quality is measured by the presence of minerals in the subsoil, i.e., the intermediate layer between the topsoil and the bedrock, and the dominant parent material comprising the underlying bedrock (for more details, see Table A2).

The slope of a region is also likely to have influenced agricultural productivity, hence regional prosperity, in former times. Slope is measured, in meters, as the difference between a region's maximum and minimum elevations. However, slope may have had an additional effect on ancient regional prosperity; transport routes probably avoided large differences in steepness or ruggedness. Proximity to the coastline, making possible a harbor and all that such implies for trade and fishing, may be another source of former regional prosperity. This importance of access to a harbor is further developed by Acemoglu et al. (2005) for European regions. We thus include a coast dummy that equals unity if a region is located along the coast.

The soil variables also allow some inferences as to a region's mineral wealth. However, as the simple presence of minerals does not necessarily imply their exploitation, we further consider the location of mining academies founded before 1800, believing them to be a good indicator of regional exploitation of mineral resources. Specifically, we consider seven locations that are or were home to a mining academy within Germany's current borders, as well as two 
locations in Silesia (now Poland) and one location in Bohemia (now the Czech Republic) (these latter three locations were a part of the German territories during our period of investigation (cf. Table A2)) and calculate each district's distance to the closest mining academy.

Column 3 of Table 1 reports the impact of the distance to the closest baroque opera house when controlling for indicators of a region's suitability for agriculture, forestry, fishing, trade, and mining. Again, the coefficient of interest changes very little.

Religious environment at the baroque opera house location: Arguably, as explained below, the former religious environment at a baroque opera house locale might very well act as a confounding factor that biases our results. This would be the case if the religious denomination of local rulers systematically affected their engagement in cultural competition and if the regional distribution of religious denominations persists to the present day and somehow influences economic outcomes. ${ }^{8}$ To arrive at a deeper understanding of how this potential bias might occur, we need to go to the beginning of the Reformation. ${ }^{9}$ The Peace of Augsburg (1555) was an attempt to end the religious conflict between the established Roman Catholic Church and the upstart Protestantism induced by Martin Luther. The Augsburg Treaty granted local rulers of the Holy Roman Empire primacy over the Emperor in imposing their preferred denomination on their subjects, a principle known as cuius regio, eius religio (whose realm, his religion). Following this treaty, there was some turbulence in the spatial distribution of religious denominations, which is nicely illustrated by Shepherd's $(1923,1926)$ maps of the religious situation in Europe around 1560, the time after the Augsburg Treaty, and 1618, when the Thirty Years' War began. After the war, the Peace of Westphalia (as contracted in 1648) fixed local religious denominations as they existed in the year 1624 and

\footnotetext{
${ }^{8}$ West and Woessmann (in press) show, for example, that the religious doctrines prevalent in the $19^{\text {th }}$ century continue to influence current school systems in OECD countries.
} 
established that a local ruler's conversion to another religion would no longer entitle him to force his subject to also convert. After this treaty, we observe a remarkably stable pattern of religious orientation that persists until this day. As a growing body of literature argues that religious denomination is related to economic outcomes (cf. Barro and McCleary 2003; Becker and Woessman 2009), there is some concern that today's cultural competition and economic situation might be simultaneously determined by religion.

To overcome this problem, Column 4 of Table 1 controls for the religious denomination at the baroque opera house location as observed at the beginning of the Thirty Years’ War, in 1618 . Our religious control includes dummies for Lutheran, Roman Catholic, Calvinist, and mixed regions (for more information, see Table A2). ${ }^{10}$ The results show that the effect of the distance to the closest baroque opera house remains robust to this control.

Hanseatic cities: We address the possibility that baroque opera house locations might coincide with early centers of trade in a second way. Those who have read Thomas Mann's famous novel Buddenbrooks, which describes the rise and fall of a trader's family in the hanseatic city of Luebeck, might argue that opera houses in hanseatic cities were not built as a result of competition between courts but to meet the increased demand by citizens for music, chiefly driven by prosperous economic development. Even though opera houses in the hanseatic cities of Brunswick, Bremen, Hamburg, Luebeck, and Rostock were built after the heyday of the Hanseatic League (between 1250 and 1400), we ran separate regressions omitting these cities when calculating distance to the closest baroque opera house (for more information, see Table A2). As reported in Column 5 of Table 1, the results remain robust to this modification.

\footnotetext{
${ }^{9}$ For a detailed overview, see Cantoni (2009).
} 
Universities: Another argument that could bias our results is one positing that those rulers who supported the musical arts were not simply patrons of the arts but also of the sciences. If this is true, one could argue that the rulers who built opera houses also founded universities, leading to an early concentration of artists and highly skilled people that persists to this day. In this case, the concentration of these skilled people might be the source of knowledge spillovers across locations. However, when looking at Table A2, one sees that only seven out of 29 cities with a baroque opera house had a university before 1800. The separate regression where we omitted these seven cities when calculating distance to the closest baroque opera house are reported in Column 6 of Table 1. Moreover, only two universities, Muenster and Brunswick, were founded during the years of the Baroque era that are of especial importance for our analyses. The results from omitting these two cities when calculating distance to the closest baroque opera house are reported in Column 7 of Table 1 . Neither specification changes our results.

Counterfactual baroque opera house locations: We additionally use matching techniques to test the reliability of our findings. In this test, we select 29 counterfactual opera house locations from the pool of regions without a baroque opera house that match the actual opera house locations in all observable characteristics except that they do not have a baroque opera house. Due to the wide range of observable characteristics, exact matching is not practicable. However, Rosenbaum and Rubin $(1984,1985)$ show that using propensity score matching, i.e., matching on the conditional probability of treatment, is a feasible way of overcoming this problem. Therefore, we concentrate on contemporary GDP per capita, soil mineralogy, parent soil, slope, coastal location, mining, religion, hanseatic cities, historic university locations (cf. Table A3), and district type as observable characteristics and then apply nearest-neighbor matching to find each baroque opera house location's twin in the control group of districts

\footnotetext{
${ }^{10}$ Note that mixed regions were basically not possible according to the Augsburg Treaty because the local ruler determined the religious denomination. However, as historic borders do not always match current borders, we
} 
that are not home to a baroque opera house. Based on the 29 counterfactual baroque opera house locations, we then calculate for each district the distance to the closest counterfactual baroque opera house and rerun the regression of Equation (1) including the control variables discussed above. Column 8 in Table 1 reports the results. Proximity to a counterfactual baroque opera house location is insignificant, making us confident that proximity to the closest actual baroque opera house location is indeed a valid and relevant measure for proximity to cultural amenities that affects the spatial equilibrium share of high-human-capital employees.

Proximity to an attractive baroque city: It might be argued that the desirability of proximity to a baroque city is more driven by the overall baroque cityscape than by the mere presence of an opera house. Among the many things that may make a city attractive are its historic architecture, including neighborhoods and parks, palaces, and castles. Due to a lack of data on such cultural amenities, we proceed inversely and analyze whether the existence of a baroque opera house is generally related to the location's concentration of bohemians. Of course, an opera house attracts not only musicians, singers, and actors, but also other bohemians, such as costumers, stage designers, and art critics. We therefore look at the contemporary spatial distribution of bohemians as derived from two datasets and regress, conditional on control variables, a district's average annual share of bohemians on a dummy that equals unity if the district is home to a baroque opera house, otherwise zero.

The first dataset (Bohemians I) stems from the German Social Insurance Statistics and covers publicists, musicians, actors, painters, and designers who are subject to social insurance. ${ }^{11}$ These data are available for 1998 to 2004. These bohemians are categorized by their place of work, not their place of residence. Therefore, the share of bohemians is calculated as the share

end up with some regions that contain more than one religious denomination.

${ }^{11}$ According to the International Standard Classification of Occupations (ISCO), these occupations are classified as ISCO Code 245, Writers and creative or performing artists. 
of people subject to social insurance in this region. The average annual share of these bohemians is 0.2 percent of a district's employees subject to social security. One might consider these dependently employed bohemians as the ones who work in and for publicly funded cultural amenities such as opera houses.

A shortcoming of the German Social Insurance Statistics is that it does not include freelancers. This is particularly troublesome when counting bohemians because many of them are freelancers. In fact, it is estimated that about half the active artists in Germany are working as freelancers and are not recorded in the Social Insurance Statistics (Haak 2005). Therefore, we gather information about freelance artists from a second database (Bohemians II), available for 2002 to 2004. These data stem from the statistics of a special insurance system (Künstlersozialkasse) created for those artists who are not in regular employment and, therefore, not subject to obligatory social insurance payments. The freelance artists included in Bohemians II provide small-scale cultural services and are engaged in fields such as writing, performing arts, fine arts, and music. In contrast to Bohemians I, they are categorized by place of residence. Accordingly, in the case of Bohemians II, we consider the share of bohemians over the resident population. The average annual share of these bohemians is another 0.2 percent of a district's resident population.

\section{$<<$ Table 2 here $>>$}

Table 2 reports the regression results: the left panel refers to Bohemians I and the right panel to Bohemians II. Irrespective of the choice of control variables or the definition of bohemians employed, the coefficient of the baroque opera house dummy has a highly significant value of 0.003 (cf. Columns 1, 2, 4, and 5 of Table 2). Hence, in districts that are home to a baroque opera house, the share of both Bohemians I and Bohemians II is 50 percent above the sample means. This suggest that even though we concentrate on baroque opera houses, which is more likely to explain the existence of dependently employed bohemians, there is also some 
explanatory power with regard to perhaps complementary small-scale cultural services. By contrast, the shares of Bohemians I and Bohemians II in the counterfactual opera house districts do not differ significantly from the sample means. In other words, this is a clear indication that actual and counterfactual opera house location are similar in regard to location factors but, in fact, differ in the extent of their cultural scenes (cf. Columns 3 and 6 of Table 2).

\section{Regional Growth and Human Capital}

Having identified an exogenous variation in the local equilibrium share of high-human-capital employees stemming from proximity to a cultural amenity, we now turn to a cross-region growth analysis in order to discover to what extent these high-human-capital individuals generate some form of local knowledge spillovers. Answering this question is of practical relevance for local governments because in the absence of positive spillovers, it is difficult to justify using taxpayer money to subsidize cultural amenities. Theories of endogenous growth (cf. Lucas 1988; Romer 1990; Aghion and Howitt 1998) emphasize that the effects of human capital are not limited to increasing labor productivity, but also lead to technological progress due to knowledge spillovers. Thus, in the presence of local knowledge spillovers, we should find a positive effect of the local level of human capital on GDP per capita growth. ${ }^{12}$ We thus estimate a simple cross-region growth regression of the following form:

$$
\Delta \log y_{i}=\alpha+\beta_{1} h_{i t=0}+\beta_{2} y_{i t=0}+D_{i} \beta_{3}+\varepsilon_{i}
$$

Here, $\Delta \log y_{i}$ is average annual GDP per capita growth over the five-year period of 1999 to 2004 in district $i$. $\mathrm{h}_{\mathrm{it}=0}$ is the initial stock of human capital measured as the share of employees with a tertiary degree. Following Barro (1991), we include initial GDP per capita $\mathrm{y}_{\mathrm{it}=0}$ to

\footnotetext{
${ }^{12}$ For a discussion, see Hanushek and Woessmann (2008: Section 4.2).
} 
control for the catching-up of poorer regions. We further control for urbanization effects by including a set of district-type dummies $\mathrm{D}_{\mathrm{i}} . \varepsilon_{i}$ is a standard error term.

\section{$<<$ Table 3 here $>>$}

As a benchmark, Column 1 of Table 3 shows the results of a simple linear least squares regression of Equation (2). Here, we find a significant positive association between average annual GDP per capita growth over a five-year period and the initial share of high-humancapital employees in the district. To be able to causally interpret this association, in a next step, we employ instrumental variable techniques and instrument in a first-stage regression the initial share of employees with a tertiary degree by the proximity to a baroque opera house as is done in Equation (1).

Columns 2 to 8 of Table 3 show the different specifications of our instrumental variable regressions results. The choice of the control variables and the subsample of the baroque opera house locations, respectively, correspond to the structure of Table 1 . In line with the regression results in Table 1, our instrument, i.e., the minimum distance to a baroque opera house, is highly relevant in the first-stage equation. Irrespective of the choice of control variables or the subsample of baroque opera house locations, the second-stage cross-region growth regressions reveal a highly significant effect of the initial share of high-human-capital employees on average annual GDP per capita growth. The effect ranges from 0.24 to 0.50 , i.e., an increase of the initial share of employees with a tertiary degree in a district by one standard deviation increases a district's average annual GDP per capita growth by about 1.0 to 2.1 percentage points. These results suggest that high-human-capital individuals are indeed an important source of local knowledge spillovers that eventually increase the growth of technological progress. Column 9 of Table 3 reports the results when using proximity to the counterfactual baroque opera house location. As already shown above, proximity to a counterfactual baroque opera house is not a relevant instrument for a district's share of high- 
human-capital employees. Therefore, it is no surprise that the instrumented share of highhuman-capital employees is not significant in the second-stage cross-region growth regression.

Wu-Hausman and Durbin-Wu-Hausman tests suggest that the IV regression coefficients are significantly higher only in the subsamples where we stepwise excluded hanseatic cities, historic university locations, and baroque university locations with a baroque opera house from the calculation of distance to the closest baroque opera house (Columns 6-8 of Table 3). In an instrumental variable approach, we estimate the mean impact of those highly qualified employees who are attracted to a district due to its proximity to a baroque opera house, i.e., what Imbens and Angrist (1994) call a local average treatment effect (LATE). In other words, the latter results suggest that it is those highly qualified employees who respond to the proximity of a baroque opera house who are the ones most relevant to economic development.

\section{Conclusions}

In this paper, we exploit exogenous variation in the spatial distribution of endogenous cultural amenities. Based on predictions derived from spatial equilibrium models with exogenous amenities, we show that the equilibrium share of high-human-capital employees is larger in regions with a high level of cultural amenities than in regions with low cultural amenities. More precisely, we show that, all else equal, for every 10 kilometers nearer to an opera house, the NUTS3 region's equilibrium share of employees with a tertiary degree increases 0.3 percentage points. Robustness tests give us confidence that this finding can be interpreted as a causal effect and not as the result of confounding factors that are correlated with both the proximity to a baroque opera house and the local share of high-human-capital employees.

To justify subsidizing cultural amenities, local governments want to know if the high-humancapital individuals who will be attracted to the region by these amenities will be the source of 
some form of local knowledge spillovers. According to our estimations, an increase of the local share of employees with a tertiary degree by one standard deviation increases average annual growth of regional GDP per capita by about 1.0 to 2.1 percentage points. The positive effect of the regional level of human capital on a region's growth path is a clear indication of local knowledge spillovers induced by the presence of high-human-capital employees.

Given the quasi-experimental design of our study, we can isolate the positive effect of cultural amenities on the regional share of high-human-capital employees and, subsequently, on regional growth. We exclude possible simultaneous effects, such as reduced spending for education and infrastructure or increased local taxes. Our advice to local policymakers is to be aware of the value of cultural amenities when competing for high-human-capital individuals. However, local policymakers should also carefully consider the possibility of unwanted side effects from redistributing resources to cultural amenities at the expense of other public spending or increased taxes because such a policy could result in relocation decisions by firms or individuals that do not value cultural amenities. 


\section{References}

Acemoglu, D., Johnson, S., Robinson, J. 2005. The Rise of Europe: Atlantic Trade, Institutional Change, and Economic Growth. American Economic Review, 95(3), 546579.

Aghion, P., Howitt, P. 1998. Endogenous Growth Theory. Cambridge, MA: MIT Press.

Arbeitsgemeinschaft Volkswirtschaftliche Gesamtrechnungen der Länder. 2008.

Bruttoinlandsprodukt, Bruttowertschöpfung in den kreisfreien Städten und Landkreisen

Deutschlands 1992 und 1994 bis 2006, Reihe 2, Band 1, Statistisches Landesamt BadenWürttemberg, Stuttgart.

Barro, R. 1991. Economic Growth in a Cross Section of Countries. Quarterly Journal of Economics, 106, 407-443.

Barro, R., McCleary, R. 2003. Religion and Economic Growth Across Countries. American Sociological Review 68, 760-781

Becker, S. O., Woessmann, L. 2009. Was Weber Wrong? A Human Capital Theory of Protestant Economic History. Quarterly Journal of Economics, 124(2), 531-596.

BBR [Federal Office for Building and Regional Planning]. 2003. Aktuelle Daten zur Entwicklung der Städte, Kreise und Gemeinden, Vol. 17, Bundesamt für Bauwesen und Raumordnung, Bonn.

Blomquist, M., Berger M., Hoehn, J. 1988. New Estimates of the Quality of Life in Urban Areas. American Economic Review, 78 , 89-107.

Bartik, T., Smith, V. 1987. Urban Amenities and Public Policy. In E. Mills (ed.), Handbook of Regional and Urban Economics: Volume 2. Amsterdam: North-Holland, pp 1207-1254. 
Buettner, T., Janeba, E. 2009. City Competition for the Creative Class. Working Paper, Ifo Institute for Economic Research, mimeo.

Cantoni, D. 2009. The Economic Effects of the Protestant Reformation: Testing the Weber Hypothesis in the German Lands. Harvard University Working Paper.

Combes, P.-P., Duranton, G., Gobillon, L., Roux, S. in press. Estimating Agglomeration Economies with History, Geology, and Worker Effects. In E. Glaeser (ed.) The Economics of Agglomeration. Chicago, IL: University of Chicago Press.

Destatis [Federal Statistical Office of Germany] 2008. Rechnungsergebnisse des oeffentlichen Gesamthaushalts 2006. Wiesbaden.

Duchhardt, H. 1992. Das Zeitalter des Absolutismus, Oldenbourg Verlag, München.

Elias, N. 1993. Mozart: Portrait of a Genius, trans. Edmund Jephcott. Berkeley, CA: University of California Press, Berkeley. The original German-language version was published in 1991.

Eulenburg, F. 1904. Die Frequenz der deutschen Universitäten von ihrer Gründung bis zur Gegenwart. Reprint 1994. Berlin: Akademie Verlag.

Florida, R. 2004. Bohemia and Economic Geography. Journal of Economic Geography, 2, 55-71.

Forsyth, M., 1985. Buildings for Music: The Architect, the Musician, and the Listener from the Seventeenth Century to the Present. Cambridge, MA: MIT Press.

Gabriel, S., Rosenthal, S. 2004. Quality of the Business Environment Versus Quality of Life: Do Firms and Households Like the Same Cities? Review of Economics and Statistics, 86, 438-444. 
Glaeser, E. 2005. Review of Richard Florida's The Rise of the Creative Class. Regional Science and Urban Economics, 35, 593-596.

Gyourko, J., Tracy, J. 1991. The Structure of Local Public Finance and the Quality of Life. Journal of Political Economy, 99, 774-806.

Haak, C. 2005. Künstler zwischen selbstständiger und abhängiger Erwerbsarbeit, Schmollers Jahrbuch [Journal of Applied Social Science Studies], 125, 573-595.

Hanushek, E., Woessmann, L. 2008. The Role of Cognitive Skills in Economic Development. Journal of Economic Literature, 46, 607-668.

Imbens, G., Angrist, J. 1994. Identification and Estimation of Local Average Treatment Effects. Econometrica, 62, 467-476.

Jacobs, J. 1961. The Death and Life of Great American Cities. New York: Random House and Vintage Books.

Kazig, R., Schweitzer, A. 2008. Die deutsche Opernlandschaft, Nationalatlas aktuell 7, Leibniz-Institut für Länderkunde (IfL), Leipzig.

Lucas, R. 1988. On the Mechanics of Economic Development. Journal of Monetary Economics, 22, 3-42.

Moretti, E. 2004. Estimating the Social Return to Higher Education: Evidence from Longitudinal and Repeated Cross-Sectional Data. Journal of Econometrics, 121(1-2), $175-212$.

Murger, H. 1845. Scènes de la vie de bohème. Reprint 1988. Paris: Editions Gallimard, Collections Folio Classique.

Rappaport, J. 2007. Moving to Nice Weather. Regional Science and Urban Economics, 37(3), $375-398$. 
Roback, J. 1982. Wages, Rents, and the Quality of Life. Journal of Political Economy, 90(60), 1257-1278.

Roback, J. (1982). Wages, Rents, and Amenities: Differences among Workers and Regions. Economic Inquiry, 26(1): 23-41.

Romer, P. 1990. Endogenous Technological Change. Journal of Political Economy, 98, S71S102.

Rosen, S. 1974. Hedonic Prices and Implicit Markets: Product Differentiation in Pure Competition. Journal of Political Economy, 82, 34-55.

Rosen, S. 1979. Wage-based Indexes of Urban Quality of Life. In P. Mieszkowski, M. Straszheim (eds.) Current Issues in Urban Economics, Baltimore: Johns Hopkins Univ. Press, pp 74-104.

Rosenbaum, P. R., Rubin, D. B. 1984. Reducing Bias in Observational Studies Using Subclassification on the Propensity Score. Journal of the American Statistical Association, 79, 516-524.

Rosenbaum, P. R., Rubin, D. B. 1985. Constructing a Control Group Using Multi-Variate Matching Methods that Include the Propensity Score. American Statistician, 39, 33-38.

Scherer, F. 2001a. Servility, Opportunity, and Freedom in the Choice of Music Composition as a Profession. Musical Quarterly, 85, 718-734.

Scherer, F. 2001b. The Evolution of Free-Lance Music Composition, 1650-1900. Journal of Cultural Economics, 25, 307-319.

Scherer, F. 2004. Quarter Notes and Bank Notes: The Economics of Music Composition in the $18^{\text {th }}$ and $19^{\text {th }}$ Centuries. Princeton, NJ: Princeton University Press. 
Shepherd, W.R. 1923. The Historical Atlas, $2^{\text {nd }}$ ed. New York: Henry Holt and Company

Shepherd, W.R. 1926. The Historical Atlas, $3^{\text {rd }}$ ed. New York: Henry Holt and Company.

Vaubel, R. 2005. The Role of Competition in the Rise of Baroque and Renaissance Music. Journal of Cultural Economics, 29, 277-297.

Vierhaus, R. 1984. Deutsche Geschichte 6. Deutschland im Zeitalter des Absolutismus, $2^{\text {nd }}$ ed. Vandenhoeck \& Ruprecht, Goettingen.

West, M., Woessmann, L. in press. "Every Catholic Child in a Catholic School”: Historical Resistance to State Schooling, Contemporary School Competition, and Student Achievement Across Countries, Economic Journal.

Zöchling, D. 1983. Opernhäuser in Deutschland, Österreich und der Schweiz. Geschichte, Ereignisse, Interpreten. Hermes-Handlexikon, Düsseldorf: ADMOS Media GmbH. 
Figure 1: Opera Houses in Germany Built Before 1800

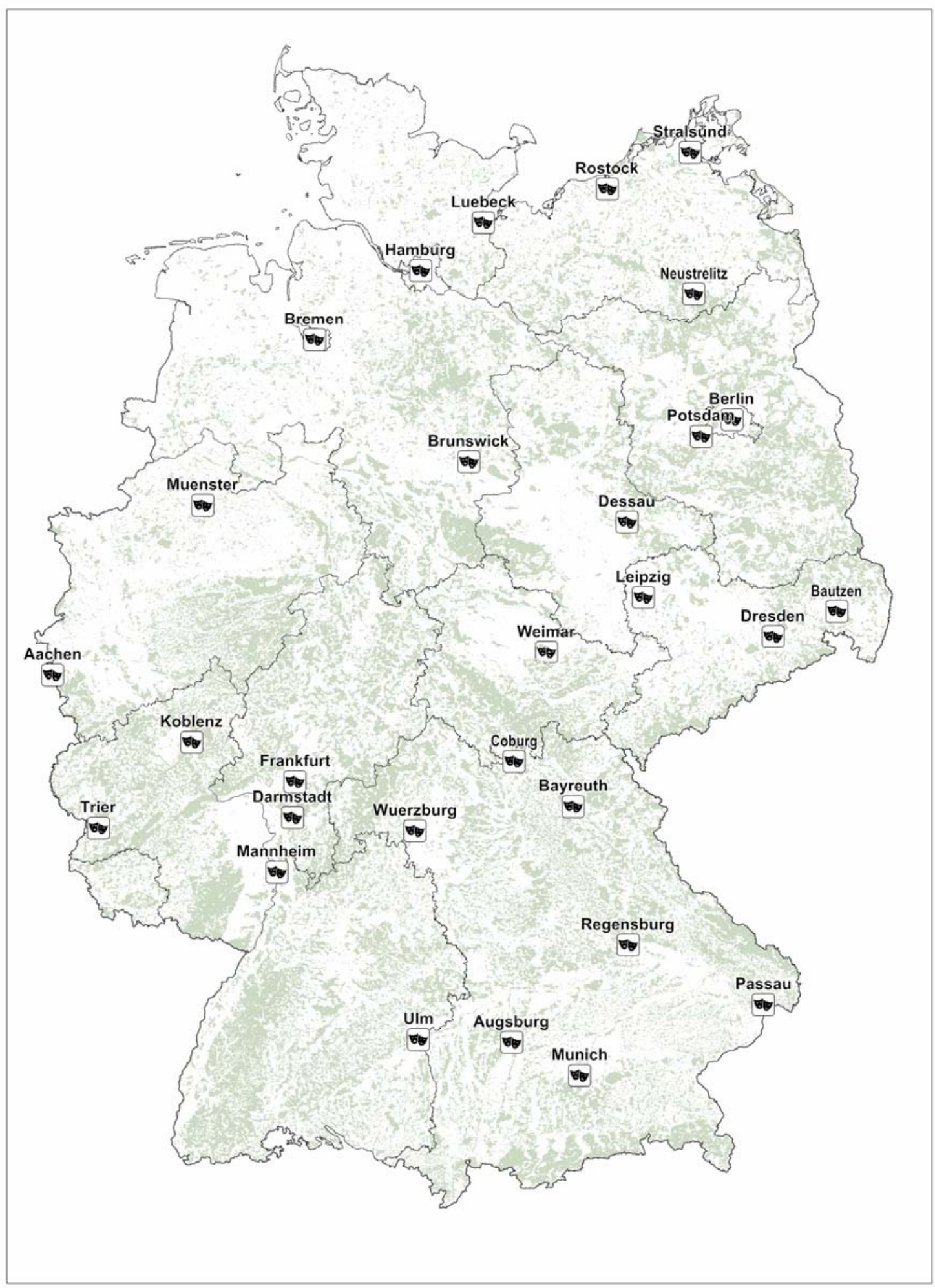

Notes: Map of the location of the 29 baroque opera houses in Germany. 
Figure 2: Distribution of Distances to the Closest Baroque Opera Houses Across Regions

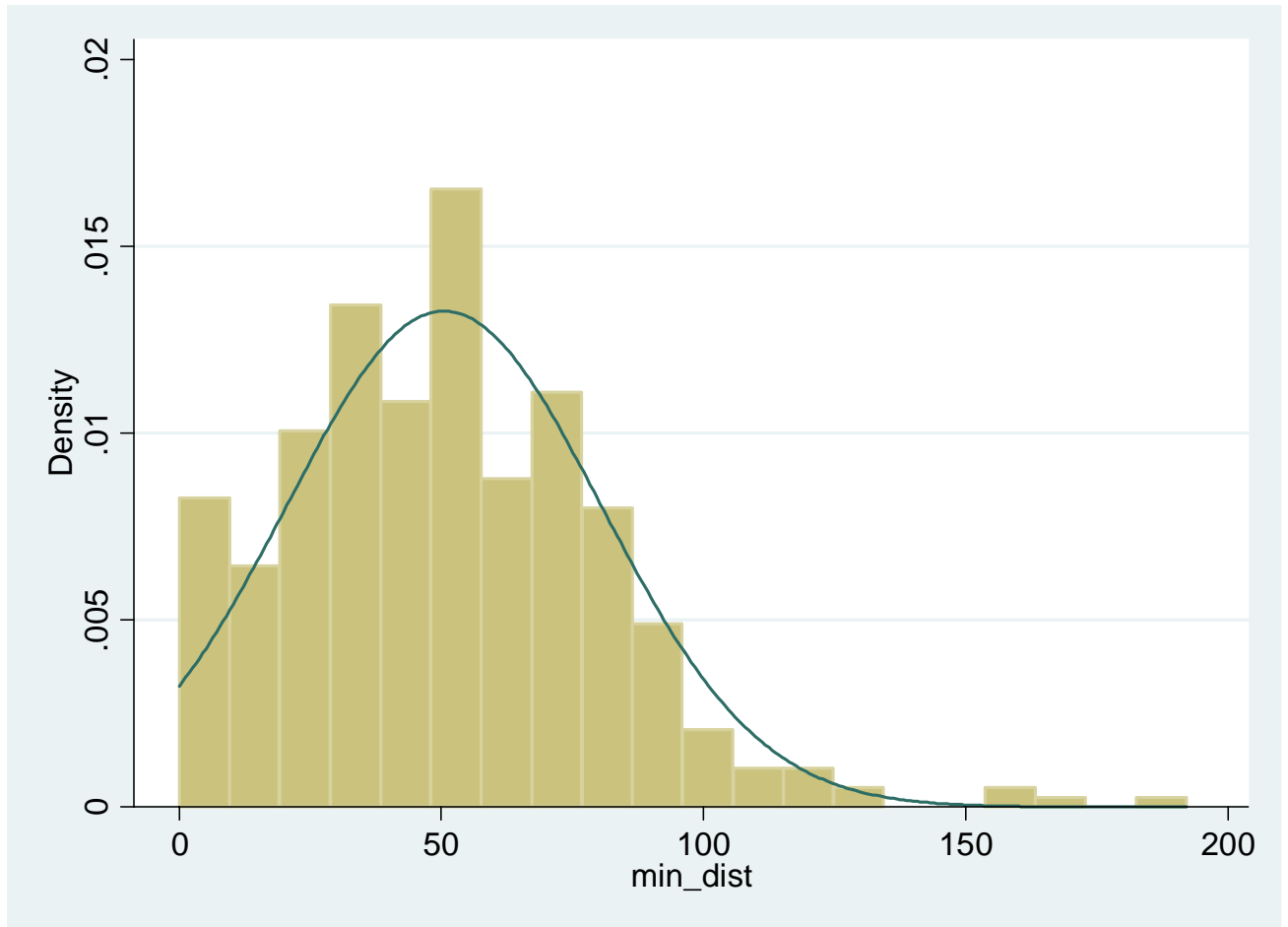

Notes: This figure shows the histogram and the smoothed density function of the distances to the closest baroque opera house (min_dist) for 403 German districts. 
Table 1: Results-High-Human-Capital Employees

\begin{tabular}{|c|c|c|c|c|c|c|c|c|}
\hline $\begin{array}{l}\text { Dependent variable: } \\
\text { Average annual share of } \\
\text { high-human-capital } \\
\text { employees 1999-2004 }\end{array}$ & $\begin{array}{c}\text { Basic } \\
\text { specification }\end{array}$ & $\begin{array}{l}\text { (2) } \\
\text { Controls current } \\
\text { prosperity in } \\
\text { district } j\end{array}$ & $\begin{array}{l}\text { (3) } \\
\text { Controls historic } \\
\text { prosperity in } \\
\text { district } j\end{array}$ & $\begin{array}{c}(4) \\
\text { Control for } \\
\text { region in district } \\
j\end{array}$ & $\begin{array}{l}\text { Hanseatic cities } \\
\text { excluded }\end{array}$ & $\begin{array}{c}(6) \\
\text { Cities with a } \\
\text { historic } \\
\text { university } \\
\text { excluded } \\
\end{array}$ & $\begin{array}{c}\text { (7) } \\
\text { Cities with a } \\
\text { baroque } \\
\text { university } \\
\text { excluded } \\
\end{array}$ & $\begin{array}{c}(8) \\
\text { Proximity to } \\
\text { counterfactual } \\
\text { opera houses }\end{array}$ \\
\hline $\begin{array}{l}\text { Distance to the closest } \\
\text { baroque opera house }\end{array}$ & $\begin{array}{c}-0.0003^{* * *} \\
(0.000)\end{array}$ & $\begin{array}{l}-0.0002 * * * \\
(0.000)\end{array}$ & $\begin{array}{l}-0.0002 * * * \\
(0.000)\end{array}$ & $\begin{array}{c}-0.0002 * * * \\
(0.000)\end{array}$ & $\begin{array}{l}-0.0003 * * * \\
(0.000)\end{array}$ & $\begin{array}{c}-0.0002^{* * *} \\
(0.000)\end{array}$ & $\begin{array}{c}-0.0002 * * * \\
(0.000)\end{array}$ & $\begin{array}{l}-0.00004 \\
(0.000)\end{array}$ \\
\hline Initial GDP p.c. (district $i$ ) & $\mathrm{Y}$ & $\mathrm{Y}$ & $\mathrm{Y}$ & $\mathrm{Y}$ & $\mathrm{Y}$ & $\mathrm{Y}$ & $\mathrm{Y}$ & $\mathrm{Y}$ \\
\hline $\begin{array}{l}\text { District-type dummies } \\
\text { (district } i \text { ) }\end{array}$ & $\mathrm{Y}$ & $\mathrm{Y}$ & $\mathrm{Y}$ & $\mathrm{Y}$ & $\mathrm{Y}$ & $\mathrm{Y}$ & $\mathrm{Y}$ & $\mathrm{Y}$ \\
\hline \multicolumn{9}{|l|}{ Controls district $\mathrm{j}$} \\
\hline Initial GDP p.c. (district j) & $\mathrm{N}$ & $\mathrm{Y}$ & $\mathrm{Y}$ & $\mathrm{Y}$ & $\mathrm{Y}$ & $\mathrm{Y}$ & $\mathrm{Y}$ & $\mathrm{Y}$ \\
\hline District type (district $j$ ) & $\mathrm{N}$ & $\mathrm{Y}$ & $\mathrm{Y}$ & $\mathrm{Y}$ & $\mathrm{Y}$ & $\mathrm{Y}$ & $\mathrm{Y}$ & $\mathrm{Y}$ \\
\hline Soil mineralogy (district $j$ ) & $\mathrm{N}$ & $\mathrm{N}$ & $\mathrm{Y}$ & $\mathrm{Y}$ & $\mathrm{Y}$ & $\mathrm{Y}$ & $\mathrm{Y}$ & $\mathrm{Y}$ \\
\hline Parent soil (district j) & $\mathrm{N}$ & $\mathrm{N}$ & $\mathrm{Y}$ & $\mathrm{Y}$ & $\mathrm{Y}$ & $\mathrm{Y}$ & $\mathrm{Y}$ & $\mathrm{Y}$ \\
\hline Slope (district $j$ ) & $\mathrm{N}$ & $\mathrm{N}$ & $\mathrm{Y}$ & $\mathrm{Y}$ & $\mathrm{Y}$ & $\mathrm{Y}$ & $\mathrm{Y}$ & $\mathrm{Y}$ \\
\hline Coast (district $j$ ) & $\mathrm{N}$ & $\mathrm{N}$ & $\mathrm{Y}$ & $\mathrm{Y}$ & $\mathrm{Y}$ & $\mathrm{Y}$ & $\mathrm{Y}$ & $\mathrm{Y}$ \\
\hline Mining (district $j$ ) & $\mathrm{N}$ & $\mathrm{N}$ & $\mathrm{Y}$ & $\mathrm{Y}$ & $\mathrm{Y}$ & $\mathrm{Y}$ & $\mathrm{Y}$ & $\mathrm{Y}$ \\
\hline Religion (district $j$ ) & $\mathrm{N}$ & $\mathrm{N}$ & $\mathrm{N}$ & $\mathrm{Y}$ & $\mathrm{Y}$ & $\mathrm{Y}$ & $\mathrm{Y}$ & $\mathrm{Y}$ \\
\hline$R^{2}$ & 0.32 & 0.49 & 0.55 & 0.55 & 0.59 & 0.58 & 0.56 & 0.54 \\
\hline F statistic & $11.96 * * *$ & $23.45^{* *}$ & $15.50 * * *$ & $14.83 * * *$ & $16.23 * * *$ & $14.97 * * *$ & $14.19 * * *$ & 13.17 \\
\hline $\begin{array}{l}\text { Number of opera house } \\
\text { locations (district } j \text { ) }\end{array}$ & 29 & 29 & 29 & 29 & 24 & 21 & 20 & 29 \\
\hline $\begin{array}{l}\text { Number of } \\
\text { observations (district } i \text { ) }\end{array}$ & 403 & 403 & 403 & 403 & 403 & 403 & 403 & 403 \\
\hline
\end{tabular}

Notes: Dependent variable is the average annual share of employees with a tertiary degree, 1998-2004, in district i ( $\mathrm{i}=1, \ldots, 403$ German NUTS3 regions). The closest baroque

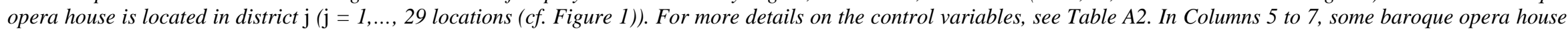
locations are excluded from the calculation of the distance to the closest baroque opera house. In Column 8, distance refers to the distance to the closest counterfactual opera house location derived from propensity score matching on observable location factors (GDP per capita, soil mineralogy, parent soil, slope, coast, mining, religion, hanseatic league, and historic university, and district type).

*** significant at the 1 percent level; ** significant at the 5 percent level; * significant at the 10 percent level. 
Table 2: Results—Contemporary Bohemians

\begin{tabular}{|c|c|c|c|c|c|c|}
\hline \multirow{2}{*}{$\begin{array}{l}\text { Dependent variable: Average } \\
\text { annual share of bohemians }\end{array}$} & \multicolumn{3}{|c|}{ Bohemians I } & \multicolumn{3}{|c|}{ Bohemians II } \\
\hline & $(1)$ & $(2)$ & (3) & (4) & (5) & (6) \\
\hline Baroque opera house dummy & $\begin{array}{c}0.003^{* * *} \\
(0.001)\end{array}$ & $\begin{array}{c}0.003^{* * *} \\
(0.001)\end{array}$ & - & $\begin{array}{c}0.003^{* * *} \\
(0.001)\end{array}$ & $\begin{array}{c}0.003^{* * *} \\
(0.001)\end{array}$ & \\
\hline $\begin{array}{l}\text { Counterfactual opera house } \\
\text { dummy }\end{array}$ & & & $\begin{array}{r}-0.0001 \\
(0.000)\end{array}$ & & & $\begin{array}{r}-0.0001 \\
(0.000)\end{array}$ \\
\hline Initial GDP per capita & $\mathrm{Y}$ & $\mathrm{Y}$ & $\mathrm{Y}$ & $\mathrm{Y}$ & $\mathrm{Y}$ & $\mathrm{Y}$ \\
\hline Soil mineralogy & $\mathrm{N}$ & $\mathrm{Y}$ & $\mathrm{Y}$ & $\mathrm{N}$ & $\mathrm{Y}$ & $\mathrm{Y}$ \\
\hline Parent soil & $\mathrm{N}$ & $\mathrm{Y}$ & $\mathrm{Y}$ & $\mathrm{N}$ & $\mathrm{Y}$ & $\mathrm{Y}$ \\
\hline Slope & $\mathrm{N}$ & $\mathrm{Y}$ & $\mathrm{Y}$ & $\mathrm{N}$ & $\mathrm{Y}$ & $\mathrm{Y}$ \\
\hline Coast & $\mathrm{N}$ & $\mathrm{Y}$ & $\mathrm{Y}$ & $\mathrm{N}$ & $\mathrm{Y}$ & $\mathrm{Y}$ \\
\hline Mining & $\mathrm{N}$ & $\mathrm{Y}$ & $\mathrm{Y}$ & $\mathrm{N}$ & $\mathrm{Y}$ & $\mathrm{Y}$ \\
\hline Religion & $\mathrm{N}$ & $\mathrm{Y}$ & $\mathrm{Y}$ & $\mathrm{N}$ & $\mathrm{Y}$ & $\mathrm{Y}$ \\
\hline District-type dummies & $\mathrm{Y}$ & $\mathrm{Y}$ & $\mathrm{Y}$ & $\mathrm{Y}$ & $\mathrm{Y}$ & $\mathrm{Y}$ \\
\hline$R^{2}$ & 0.37 & 0.40 & 0.31 & 0.39 & 0.42 & 0.32 \\
\hline F statistic & $15.97 * * *$ & $7.49 * * *$ & $6.97 * * *$ & $16.78 * * *$ & $7.40^{* * *}$ & $7.11^{* * *}$ \\
\hline $\begin{array}{l}\text { Number of } \\
\text { observations }\end{array}$ & 403 & 403 & 403 & 403 & 403 & 403 \\
\hline
\end{tabular}

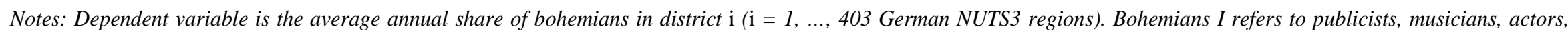
painters, and designers covered by the German Social Insurance Statistics. These data are available from 1998 to 2004. Bohemians II refers artists who are not in regular employment and who are covered by a special insurance (Kuenstlersozialkasse). The data are available from 2002 to 2004 . The baroque opera house dummy equals unity for 29

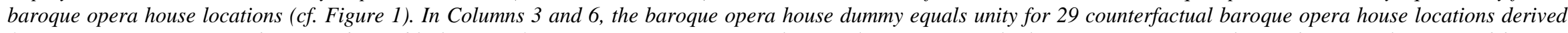

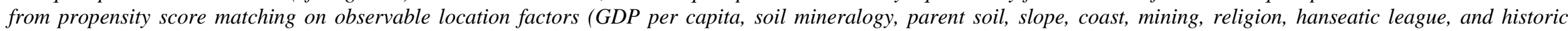
university, and district type). For more details on the control variables, see Table A2.

*** significant at the 1 percent level; ** significant at the 5 percent level; * significant at the 10 percent level. 
Table 3: Results-Annual GDP per Capita Growth

\begin{tabular}{|c|c|c|c|c|c|c|c|c|c|}
\hline \multirow{3}{*}{$\begin{array}{l}\text { Dependent variable: } \\
\text { Average annual GDP } \\
\text { per capita growth } \\
\text { 1999-2004 }\end{array}$} & (1) & (2) & (3) & (4) & (5) & (6) & (7) & (8) & (9) \\
\hline & OLS & IV & IV & IV & IV & IV & IV & IV & IV \\
\hline & $\begin{array}{c}\text { Basic } \\
\text { specification }\end{array}$ & $\begin{array}{c}\text { Basic } \\
\text { specification }\end{array}$ & $\begin{array}{l}\text { Controls } \\
\text { current } \\
\text { prosperity in } \\
\text { district } j\end{array}$ & $\begin{array}{l}\text { Controls } \\
\text { historic } \\
\text { prosperity in } \\
\text { district } j\end{array}$ & $\begin{array}{l}\text { Control for } \\
\text { region in } \\
\text { district } j\end{array}$ & $\begin{array}{l}\text { Hanseatic } \\
\text { cities } \\
\text { excluded }\end{array}$ & $\begin{array}{l}\text { Cities with a } \\
\text { historic } \\
\text { university } \\
\text { excluded }\end{array}$ & $\begin{array}{l}\text { Cities with a } \\
\text { baroque } \\
\text { university } \\
\text { excluded }\end{array}$ & $\begin{array}{l}\text { Proximity to } \\
\text { counterfactual } \\
\text { opera houses }\end{array}$ \\
\hline $\begin{array}{l}\text { Initial human capital } \\
\text { (district } i \text { ) }\end{array}$ & $\begin{array}{l}0.29 * * * \\
(0.028)\end{array}$ & $\begin{array}{l}0.41 * * * \\
(0.104)\end{array}$ & $\begin{array}{l}0.33^{* *} \\
(0.164)\end{array}$ & $\begin{array}{l}0.240^{*} \\
(0.146)\end{array}$ & $\begin{array}{l}0.243^{*} \\
(0.133)\end{array}$ & $\begin{array}{c}0.464^{* * *} \\
(0.080)\end{array}$ & $\begin{array}{c}0.448 * * * \\
(0.072)\end{array}$ & $\begin{array}{c}0.494^{* * *} \\
(0.067)\end{array}$ & $\begin{array}{c}1.259 \\
(1.613)\end{array}$ \\
\hline $\begin{array}{l}\text { Initial GDP p.c. } \\
\text { (district } i \text { ) }\end{array}$ & $\mathrm{Y}$ & $\mathrm{Y}$ & $\mathrm{Y}$ & $\mathrm{Y}$ & $\mathrm{Y}$ & $\mathrm{Y}$ & $\mathrm{Y}$ & $\mathrm{Y}$ & $\mathrm{Y}$ \\
\hline $\begin{array}{l}\text { District-type dummies } \\
\text { (district } i \text { ) } \\
\text { Controls district } j\end{array}$ & $\mathrm{Y}$ & $\mathrm{Y}$ & $\mathrm{Y}$ & $\mathrm{Y}$ & $\mathrm{Y}$ & $\mathrm{Y}$ & $\mathrm{Y}$ & $\mathrm{Y}$ & $\mathrm{Y}$ \\
\hline $\begin{array}{l}\text { Initial GDP p.c. } \\
\text { (district } j \text { ) }\end{array}$ & $\mathrm{N}$ & $\mathrm{N}$ & $\mathrm{Y}$ & $\mathrm{Y}$ & $\mathrm{Y}$ & $\mathrm{Y}$ & $\mathrm{Y}$ & $\mathrm{Y}$ & $\mathrm{Y}$ \\
\hline District type district $j$ ) & $\mathrm{N}$ & $\mathrm{N}$ & $\mathrm{Y}$ & $\mathrm{Y}$ & $\mathrm{Y}$ & $\mathrm{Y}$ & $\mathrm{Y}$ & $\mathrm{Y}$ & $\mathrm{Y}$ \\
\hline $\begin{array}{l}\text { Soil mineralogy } \\
\text { (district } j \text { ) }\end{array}$ & $\mathrm{N}$ & $\mathrm{N}$ & $\mathrm{N}$ & $\mathrm{Y}$ & $\mathrm{Y}$ & $\mathrm{Y}$ & $\mathrm{Y}$ & $\mathrm{Y}$ & $\mathrm{Y}$ \\
\hline Parent soil (district $j$ ) & $\mathrm{N}$ & $\mathrm{N}$ & $\mathrm{N}$ & Y & $\mathrm{Y}$ & $\mathrm{Y}$ & $\mathrm{Y}$ & $\mathrm{Y}$ & $\mathrm{Y}$ \\
\hline Slope (district j) & $\mathrm{N}$ & $\mathrm{N}$ & $\mathrm{N}$ & Y & $\mathrm{Y}$ & $\mathrm{Y}$ & $\mathrm{Y}$ & $\mathrm{Y}$ & $\mathrm{Y}$ \\
\hline Coast (district $j$ ) & $\mathrm{N}$ & $\mathrm{N}$ & $\mathrm{N}$ & $\mathrm{Y}$ & $\mathrm{Y}$ & $\mathrm{Y}$ & $\mathrm{Y}$ & $\mathrm{Y}$ & $\mathrm{Y}$ \\
\hline Mining (district $j$ ) & $\mathrm{N}$ & $\mathrm{N}$ & $\mathrm{N}$ & $\mathrm{Y}$ & $\mathrm{Y}$ & $\mathrm{Y}$ & $\mathrm{Y}$ & $\mathrm{Y}$ & $\mathrm{Y}$ \\
\hline Religion (district $j$ ) & $\mathrm{N}$ & $\mathrm{N}$ & $\mathrm{N}$ & $\mathrm{N}$ & $\mathrm{Y}$ & $\mathrm{Y}$ & $\mathrm{Y}$ & $\mathrm{Y}$ & $\mathrm{Y}$ \\
\hline$R^{2}$ & 0.32 & 0.27 & 0.35 & 0.43 & 0.44 & 0.28 & 0.31 & 0.27 & 0.20 \\
\hline F statistic & $14.40 * * *$ & $4.59 * * *$ & $15.11^{* * *}$ & $10.24 * * *$ & $9.30 * * *$ & $7.91 * * *$ & $8.10 * * *$ & $7.07 * * *$ & $1.85 * * *$ \\
\hline \multicolumn{10}{|l|}{ First stage } \\
\hline $\begin{array}{l}\text { Distance to the closest } \\
\text { baroque opera house }\end{array}$ & - & $\begin{array}{c}-0.0003^{* * *} \\
(0.000)\end{array}$ & $\begin{array}{c}-0.0002 * * * \\
(0.000)\end{array}$ & $\begin{array}{c}-0.0002 * * * \\
(0.000)\end{array}$ & $\begin{array}{c}-0.0002 * * * \\
(0.000)\end{array}$ & $\begin{array}{c}-0.0003 * * * \\
(0.000)\end{array}$ & $\begin{array}{c}-0.0003 * * * \\
(0.000)\end{array}$ & $\begin{array}{c}-0.0002 * * * \\
(0.000)\end{array}$ & $\begin{array}{l}-.00004 \\
(0.000)\end{array}$ \\
\hline $\begin{array}{l}\text { F-test (excluded } \\
\text { instrument) }\end{array}$ & - & $22.01 * * *$ & $10.79 * * *$ & $12.93 * * *$ & $15.50 * * *$ & $60.79 * * *$ & $69.85 * * *$ & $81.42 * * *$ & $0.48 *$ \\
\hline Wu-Hausman F-test & - & 1.47 & 0.71 & 0.12 & 0.17 & $14.33^{* * *}$ & $13.50 * * *$ & $18.69 * *$ & 2.09 \\
\hline $\begin{array}{l}\text { Durbin-Wu-Hausman } \\
\text { chi }^{2} \text { test }\end{array}$ & - & 1.51 & 0.73 & 0.13 & 0.19 & $14.83 * * *$ & $14.00 * * *$ & $19.13 * *$ & 2.24 \\
\hline $\begin{array}{l}\text { Number of opera house } \\
\text { locations (district } j \text { ) }\end{array}$ & 29 & 29 & 29 & 29 & 29 & 24 & 21 & 20 & 29 \\
\hline $\begin{array}{l}\text { Number of } \\
\text { observations }\end{array}$ & 403 & 403 & 403 & 403 & 403 & 403 & 403 & 403 & 403 \\
\hline
\end{tabular}

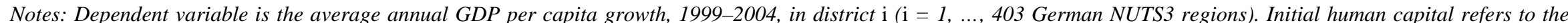

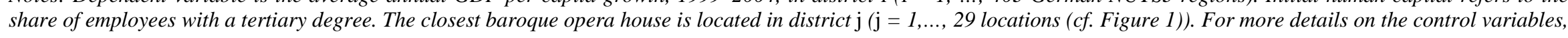


see Table A2. In Columns 6 to 8, some baroque opera house locations are excluded from the calculation of the distance to the closest baroque opera house. In Column 9,

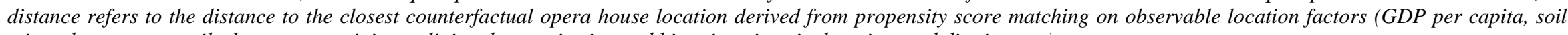
mineralogy, parent soil, slope, coast, mining, religion, hanseatic city, and historic university location, and district type).

*** significant at the 1 percent level; ** significant at the 5 percent level; * significant at the 10 percent level. 
Table A1: Historic Locations of Opera Houses Built Before and Near 1800

\begin{tabular}{lcl}
\hline \hline Location & Year of Construction & Description \\
\hline Aachen & 1751 & $\begin{array}{l}\text { Aachen's first public opera house opened its doors in 1751. Aachen's town master builder Johann Joseph Couven rebuilt a bathhouse } \\
\text { into an opera house. It was located at the Katschhof. }\end{array}$
\end{tabular}

Augsburg

1776

Bautzen

Bayreuth

Berlin

Brunswick

1690

Bremen

Coburg
Augsburg's first opera house, the Städtische Schauspielhaus, was built on a large scale, providing the capacity to host prestigious ensembles and orchestras. Among others, Mozart visited the opera house in October 1777 and his opera, Don Giovanni, was staged in 1787, the year of its world premiere.

Bautzen's opera house was established in the inner part of the city wall, located between Lauengraben and Kornmarkt. Mozart's Zauberflöte had its world premiere here in 1791.

The opera house bears witness to the artistic disposition of the Margrave's wife Wilhelmine, Princess of Prussia and sister of Fredrick the Great. Its outer parts were built by Joseph Saint-Pierre, the inner parts were built by Giuseppe and Carlo Galli-Bibiena.

Fredrick the Great engaged Georg Wenzeslaus von Knobelsdorff to build the opera house. Construction work started in July 1741 . The impatient ruler demanded its inauguration on December 7, 10 months before the actual completion, with Carl Heinrich Graun's opera Cleopatra e Cesare.

The opera house in was built on behalf of Duke Anton Ulrich von Braunschweig-Lüneburg. It was located at the Hagenmarkt. In addition to operas, the house hosted the premiere of Gotthold Ephraim Lessing's play Emilia Galotti in 1772.

Bremen's first opera house, called Altes Schauspielhaus, was built by Carl Ludwig Murtfeldt on the Junkernbastion in proximity to the Ostertor. It was inaugurated with Joseph Marius von Babo’s play Bürgerglück, evidence that it hosted plays as well as operas. Among the most popular composers performed in Bremen were Paisiello, Mozart, and Ditters von Dittersdorf.

Coburg was the ducal seat of the Dukes of Saxony-Coburg. Duke Albrecht opened Coburg's first court theater in 1684. After his death performances stopped until Duke Ernst Friedrich rebuilt the former ball house at the Schlossarkaden into an opera house and theater. Performances then included operas by Mozart and plays by Schiller and Iffland. 
Darmstadt's first theater was built on behalf of the Landgrave's wife Elisabeth Dorothea. The previous riding arena at Herrengarten was rebuilt into an opera house by Louis Remy de La Fosse. It was inaugurated with Christoph Graupners opera Telemach.

In 1798, Prince Leopold Friedrich Franz engaged Friedrich Wilhelm von Erdmannsdorff to build an opera house. It was inaugurated with the opera Bathmendi by the newly hired artistic director Freiherr Carl August Ludwig von Lichtenstein.

At the beginning of the 17th century, Dresden's Kursächsische Staatskapelle, which served as an opera house, became too small and was replaced by the first dedicated opera house, built by J. A. Haase. It opened its doors in 1718. In 1755, a second opera house opened its doors. It was called Kleines Hoftheater (little court theater) to distinguish it from the existing opera house.

Frankfurt's theater and opera house was designed and built by town master builder Johann Andreas Liebhardt. The desire to have a theater was probably stimulated by the establishment of Mannheim's theater and opera house in 1777. The theater was inaugurated with the play Hanno, Fürst in Norden. However, operas were also popular, especially ones by Mozart.

The opera house in Hamburg, built by Girolamo Sartorio, was located at the Gänsemarkt. It was inaugurated with the musical comedy Adam und Eva oder Der Erschaffene, Gefallene und Aufgerichtete Mensch by Johann Theile.

Koblenz's opera house was built on behalf of Trier's Archbishop Clemens Wenzeslaus of Saxony. It was built by the architect Peter Sachsen in the part of town called Neustadt. The opera house was inaugurated with Mozart's opera Die Entführung aus dem Serail.

Leipzig's first opera house, built in 1693, was located at the Brühl, partly on ground of the previous Bernhardinerkollegs, a college. Since the opera house did not have its own orchestra, there was traditionally a close cooperation with the Gewandhausorchster, the orchestra of the nearby Gewandhaus theater. The cooperation probably dates back to the year 1766 when the musical comedy Der Teufel ist los oder Die verwandelten Weiber by Johann Adam Hiller was performed. 
Luebeck
Luebeck's theater and opera tradition dates back to the carpenter Hermann Hinrich Schröder, who frequently invited actors to his house in Königsstraße. In 1751, Schröder was granted official permission to perform plays in his house. The first opera performance in Luebeck dates to the year 1746 when an Italian group of actors headed by Pietro Mingotti presented the opera Ipermestra. To perform an opera in Schröder's house, they had to rebuild the house. With his increasing success, Schröder needed a larger place and finally found the vacant Lüneburger Hof located in the Beckergrube. The theater was later renamed the Ebbesches Theater. From 1799 on, Luebeck's theater and opera house were home to a permanent ensemble.

Mannheim's opera house was established on behalf of Elector Karl Theodor, who initiated the rebuilding of the arsenal into an opera house. Builder Lorenzo Quaglio did this job and enlarged and beautified the building. Karl Theodor hired Johann Stamitz as instrumental-music director and instructed him to reform and enlarge the court orchestra. Moreover, Karl Theodor also supported the development of a formerly unknown instrumental style that became known as the Mannheimer Schule. Finally, Karl Theodor also supported the renewal of the prevailing understanding of the opera. In doing so, he argued in support of German-language operas as an alternative to Italian operas.

Elector Ferdinand Maria and his wife Gattin Henriette Adelaide founded Munich's first independent ensemble. It performed in their residence until the Venetian builder Francesco Santurini was hired to construct Munich's first opera house at Salvatorplatz in 1657. A second opera house was built between 1751 and 1753 by François de Cuvilliés, architect to the court.

Elector Franz Freiherr von Fürstenberg established Münster's theater and opera tradition when he instructed mason Wilhelm Ferdinand Lipper to rebuild the slaughterhouse located at the Roggenmarkt into Münster's first theater and opera house, the so-called Komödienhaus. Performances included musical comedies and operas.

The theater and opera house in Neustrelitz was built in French style between 1755 and 1758. In 1769, it was rebuilt by builder Martin Seydel and from 1775 on it was the permanent court theater.

The opera house was built on behalf of Prince-Bishop Leopold Wilhelm von Österreich in 1664 and initially served as a dance hall for the popular Spanish balls. About 100 years later, around 1773, Prince-Bishop Ernst Leopold Kardinal Graf von Firmian tuned the ball house into a court theater and opera house and, finally, Prince-Bishop Joseph Kardinal Graf von Auersperg opened its doors to the public in 1783. The public opera house was inaugurated in 1783 with Anton Schweiter's opera Alceste.

The theater and opera house was initiated by King Friedrich Wilhelm II and is located along the canal. Because of its location, it is also known as Kanaloper, the "channel opera house." 
Regensburg

Rostock

Stralsund

Trier

Ulm

Weimar

1779

Wuerzburg
The theater and opera house in Regensburg is located at the Bismarkplatz. The construction plan stems from Emanuel Herigoyen and it was built at Elector, Archbishop, and Imperial Chancellor Carl Theodor von Dalberg's suggestion. Previously, from 1760 to 1804 , there was a theater located within the dance hall.

Until 1786, traveling groups of artists performed in Rostock at different locations, including the Ballhaus and the Comödienhaus. From then on, however, performances took place in the newly built theater and opera house.

In 1765, a building that had already been serving as a theater was rebuilt and turned into Stralsund's theater and opera house, located in Mönchstrasse. Previously, the building had been an orphanage. The theater and opera house was inaugurated with a masquerade ball.

Even though it was known as a place for music and theater performances ever since the electoral times in the $17^{\text {th }}$ century, Trier did not have a permanent theater and opera house until the beginning of the $18^{\text {th }}$ century. Then, in 1802, a contract between the French prefect and the proprietor Schaak, Jr laid the groundwork for the first permanent theater and opera house in the former Capuchin monastery.

In 1641, town master mason Joseph Furttenbach rebuilt the former granary at the Binderhof close by the Dominicans' monastery into an early version of a theater. It already had curtains and an orchestra and it was equipped with the latest Italian technology, i.e., rotatable scenery. The theater attracted artists from all over Europe who performed together with the permanent actors.

Duke Ernst August II Konstantin von Sachsen-Weimar-Eisenach’s wife, Anna Amalia, always supported German musical comedy, French plays, and operas. There were a variety of stages spread across the city on which performances took place regularly. Then, in 1779, a theater was built and in 1791 Duke Carl August turned this theater into Weimar's court theater. Goethe became the director of the theater, whose inaugural performance was Iffland's play Die Jäger.

Julius Earl Soden is the founder of Würzburg's theater and opera house. The theater was located in the Adligen Damenstift Heilige Anna, which was rebuilt into a theater and opera house. It was inaugurated with the play Stille Wasser sind tief.

Notes: Columns 1-3 provide information about the location and the year of construction of the 29 historic theaters or opera houses.

Sources: Forsyth (1985), Kazig and Schweitzer (2008), Zöchling (1983), and own research. 
Table A2: Extended Data Description

\begin{tabular}{l|l}
\hline Variable & Description and Source \\
\hline
\end{tabular}

Bohemians I

The number of Bohemians I in a district is derived from the German Social Insurance Statistics; covers publicists, musicians,

actors, painters, and designers who are subject to social insurance. These data are available from 1998 to 2004. These

bohemians are categorized by their place of work, not their place of residence. Therefore, the share of bohemians is calculated

as the share of people subject to social insurance in this region. A shortcoming of the German Social Insurance Statistics is

that it does not include entrepreneurs, freelancers, or civil servants. This is particularly troublesome when counting bohemians because many of them are freelancers.

The number of Bohemians II is derived from a special insurance system (Künstlersozialkasse) created for those artists who are not in regular employment and, therefore, not subject to obligatory social insurance payments. The freelance artists included

Bohemians II in Bohemians II are engaged in the fields of writing, performing arts, fine arts, and music. In contrast to Bohemians I, they are categorized by place of residence. Accordingly, in the case of Bohemians II, we consider the share of bohemians over the resident population.

Coast

This variable is a dummy that equals unity if the district has direct access to the coast, otherwise zero.

This variable is based on a standard classification of German districts (siedlungsstrukturelle Kreistypen) according to their density and their spatial status (cf. BBR 2003) and is a scale of the following nine types.

1. City districts in highly agglomerated areas with more than 100,000 inhabitants

2. Districts in highly agglomerated areas with a population density of more than 300 inhabitants per $\mathrm{km}^{2}$

3. Districts in highly agglomerated areas with a population density of more than 150 inhabitants per $\mathrm{km}^{2}$

4. Districts in highly agglomerated areas with a population density of less than 150 inhabitants per km²

District type

5. City districts in urbanized areas with more than 100,000 inhabitants

6. Districts in urbanized areas with a population density of more than 150 inhabitants per $\mathrm{km}^{2}$

7. Districts in urbanized areas with a population density of less than 150 inhabitants per $\mathrm{km}^{2}$

8. Districts in rural areas with a population density of more than 100 inhabitants per $\mathrm{km}^{2}$

9. Districts in rural areas with a population density of less than 100 inhabitants per $\mathrm{km}^{2}$

In the cases where we have merged the city districts with the surrounding territorial districts, the classification of a merged district refers to this surrounding territorial district.

GDP per Capita

District-level GDP per capita is provided by the Statistical Offices (Arbeitsgemeinschaft Volkswirtschaftliche Gesamtrechnung der Länder 2008).

Hanseatic League

The last meeting of representatives of the Hanseatic League cities took place in Luebeck in 1669. At this time, Luebeck,

Hamburg, Bremen, Danzig, Rostock, Brunswick, Hildesheim, Osnabrueck, and Cologne belonged to the Hanseatic League.

Data on high-human-capital employees are derived from the German Social Insurance Statistics. The German Social

Insurance Statistics requires every employer to report information about each employee subject to compulsory social

insurance. Thus, employees are not categorized by their place of residence but by their workplace (establishment). Our human

capital measure is simply the share of employees subject to social insurance with a tertiary (university) degree over all

employees subject to social insurance in a district. 
Variable

\section{Description and Source (continued)}

This variable represents the minerals in the subsoil, i.e., the intermediate layer between the topsoil and the bedrock. This

variable is a scale of the following eight characteristics (only five apply to Germany).

1. $\mathrm{KQ}=1 / 1$ Minerals + Quartz

2. $\mathrm{KX}=1 / 1 \mathrm{Min} .+$ Oxy. and Hydroxy.

3. $\quad \mathrm{MK}=2 / 1$ and $1 / 1$ Minerals

4. $(\mathrm{M}=2 / 1$ and $2 / 1 / 1$ Non Swel. Minerals)

5. $\mathrm{MS}=$ Swel. and Non Swel. $2 / 1$ Minerals

6. $\mathrm{S}=$ Swelling $2 / 1$ Minerals

7. $\mathrm{TV}=$ Vitric Minerals

8. $\mathrm{TO}=$ Andic Minerals

Data stem from the European Soil Database (esdb) and are compiled by the European Soil Data Centre. A more detailed description of the variable and its generation process is provided in Combes et al. (in press).

Mining is calculated as the distance from the district's centoid to the closest mining academy that was founded before the Industrial Revolution. These mining academies are Clausthal, founded in 1775, Eisleben, founded in 1798, Freiberg, founded in 1765, Königshütte, founded in 1803, Bad Steben, founded in 1793, Tarnowitz (Upper Silesia), founded in 1803, and St. Joachimsthal (Bohemia), founded in 1717.

This variable represents the dominant parent material in the soil. This variable is a scale of the following eight characteristics.

1. Consolidated-clastic-sedimentary rocks

2. Sedimentary rocks (chemically precipitated, evaporated, or organogenic or biogenic in origin)

3. Igneous rocks

4. Metamorphic rocks

Parental Soil

Unconsolidated deposits (alluvium, weathering residuum, and slope deposits)

6. Unconsolidated glacial deposits/glacial drift

7. Eolian deposits

8. Organic materials

Data from the European Soil Database (esdb) and are compiled by the European Soil Data Centre. A more detailed description of the variable and its generation process is provided in Combes et al. (in press).

Religion represents the religious denomination of a region in 1618. The variable is a scale of the following four

characteristics.

1. Lutheran regions

2. Roman Catholic regions

3. Calvinist regions

4. Mixed regions

Note that mixed regions were basically not possible according to the Augsburg Treaty because the local ruler determined the religious denomination. However, as historic borders do not always match current borders, we end up with some regions that contain two of the three religions. The information stems from Shepherd's (1923) map, The Religious Situation in Central Europe about 1618, and was further edited in GIS

\begin{tabular}{|l|l} 
Slope $^{\mathrm{a}}$ & Slope is measured as the difference between the maximum and minimum elevations in meters. \\
\hline
\end{tabular}


Table A3: University Locations Before 1800

\begin{tabular}{|c|c|c|c|}
\hline Location & Year of Foundation & Hanseatic City & Opera House \\
\hline Altdorf & 1522 & no & no \\
\hline Bamberg & 1648 & no & no \\
\hline Cologne & 1388 & yes & no \\
\hline Dillingen & 1554 & no & no \\
\hline Duisburg & 1655 & no & no \\
\hline Erfurt & 1392 & no & no \\
\hline Erlangen & 1743 & no & no \\
\hline Frankfurt (Oder) & 1506 & no & no \\
\hline Freiburg & 1460 & no & no \\
\hline Fulda & 1734 & no & no \\
\hline Gießen & 1607 & no & no \\
\hline Goettingen & 1737 & no & no \\
\hline Greifswald & 1456 & no & no \\
\hline Halle & 1694 & no & no \\
\hline Heidelberg & 1386 & no & no \\
\hline Helmstedt & 1516 & no & no \\
\hline Herborn & 1584 & no & no \\
\hline Ingolstadt & 1472 & no & no \\
\hline Jena & 1558 & no & no \\
\hline Kassel & 1633 & no & no \\
\hline Kiel & 1665 & no & no \\
\hline Leipzig & 1409 & no & yes \\
\hline Mainz & 1477 & no & no \\
\hline Marburg & 1527 & no & no \\
\hline Muenster & 1780 & no & yes \\
\hline Osnabrueck & 1630 & no & no \\
\hline Paderborn & 1615 & no & no \\
\hline Rinteln & 1621 & no & no \\
\hline Rostock & 1419 & yes & yes \\
\hline
\end{tabular}




\begin{tabular}{|c|c|c|c|}
\hline & & & \\
\hline Stuttgart & 1781-94 & no & no \\
\hline Trier & 1473-1798 & no & yes \\
\hline Tuebingen & 1477 & no & no \\
\hline Wittenberg & $1502-1817$ & no & no \\
\hline Wuerzburg & 1582 & no & yes \\
\hline
\end{tabular}

Source: Eulenburg (1904). 